інноваційних університетських комплексів : автореф. дис. на здобуття наук. ступеня д-ра наук 3 державного управління : 25.00.02 / Л. П. Полякова; Донец. держ. ун-т управління. - Донецьк, 2010. - 36 с. 6. Розина И. Н. Педагогическая компьютерноопосредованная коммуникация как прикладная область коммуникативных исследовании [Электронный ресурс]/ И. Н. Розина. - Режим доступа: http://ifets.ieee.org/ Russian/depository/v8_ 12/html 7. Щолок О. Б. Інформаційнонавчальне середовище як чинник формування компетентності самоосвіти у майбутнього фахівця / О. Б. Щолок // Освітнє середовище як методична проблема: [зб. наук. праць]. - Херсон : Вид-во ХДУ. - 2006. - С. 183-184.

Юлія Остраус

\title{
ДЕЯКІ ПІДХОДИ ДО ВИЗНАЧЕННЯ СУТНОСТІ ПОНЯТТЯ «ПРОФЕСІЙНЕ САМОВДОСКОНАЛЕННЯ МАЙБУТНІХ СІМЕЙНИХ ЛІКАРІВ»
}

Остраус Ю. М. Деякі підходи до визначення сутності поняття «професійне самовдосконалення майбутніх сімейних лікарів».

У статті здійснено теоретичний аналіз підходів науковців-педагогів до тлумачення понять «самовдосконалення» та «професійне самовдосконалення», розкрито сутність поняття «професійне самовдосконалення майбутніх сімейних лікарів».

Ключові слова: самовдосконалення, професійне самовдосконалення, самовиховання, професійне самовдосконалення майбутніх сімейних лікарів.

Остраус Ю. М. Некоторые подходы к определению сущности понятия «профессиональное самосовершенствование будущих семейных врачей».

В статье представлен теоретический анализ подходов ученых-педагогов к толкованию понятий «самосовершенствование» и «профессиональное самосовершенствование», раскрывается сущность понятия «профессиональное самосовершенствование будущих семейных врачей».

Ключевые слова: самосовершенствование, профессиональное самосовершенствование, самовоспитание, профессиональное самосовершенствование будущих семейных врачей.

Ostraus Y. M. Some approaches to the definition of the notion «future family doctor's professional self-improvement».

The author analyses the pedagogical approaches to the definition of the terms «selfimprovement» and «professional self-improvement». The meaning of the notion «future family doctor's professional self-improvement» is defined.

Key words: self-improvement, professional self-improvement, self-discipline, future family doctor's professional self-improvement.

Проблема підвищення якості підготовки майбутніх сімейних лікарів стала особливо актуальною на сучасному етапі розвитку нашої країни, коли розпочато роботу 3 реформування системи охорони здоров'я України. Модернізація всієї галузі тісно пов'язана з переходом до сімейної медицини, який дозволить зробити охорону здоров'я більш гнучкою, конкурентною і наближеною до потреб пацієнтів. Належне функціонування первинної ланки медичної допомоги повністю залежить від сімейних лікарів, які повинні мати більш високу кваліфікацію, ніж звичайні 
дільничні лікарі. Відповідно, сучасні сімейні лікарі повинні постійно працювати над власним самовдосконаленням.

Протягом останнього десятиріччя підвищився інтерес українських науковців до проблеми професійного самовдосконалення майбутніх фахівців. Зокрема О. Діденко вивчав умови професійного самовдосконалення майбутніх офіцерів, Л. Дудікова досліджувала формування готовності до професійного самовдосконалення у майбутніх лікарів. О. Ігнатюк розглядав підготовку майбутнього інженера до професійного самовдосконалення в умовах технічного університету. М. Костенко аналізувала педагогічні умови професійно-творчого саморозвитку майбутнього вчителя. В. Артюхова, Я. Подоляк, Я. Шведова провели досить глибоке дослідження самовдосконалення студентів вищих навчальних закладів. Л. Сущенко працювала над проблемою стимулювання професійного самовдосконалення вчителів початкових класів у системі післядипломної освіти. Водночас необхідно зауважити, що незначна кількість наукових праць присвячена професійному самовдосконаленню саме майбутніх лікарів.

Метою статті є теоретичний аналіз підходів науковців-педагогів до тлумачення понять «самовдосконалення» та «професійне самовдосконалення», розкриття сутності поняття «професійне самовдосконалення майбутніх сімейних лікарів».

Ідеї самовдосконалення особистості знайшли втілення у працях видатних педагогів минулого Я. Коменського та І. Песталоцці, які визнавали необхідність виховувати в особи потребу постійного розвитку та самовдосконалення. К. Ушинський уважав самовдосконалення одним із завдань професійної діяльності вчителів і визначав його як поєднання саморозвитку, самоосвіти і самовиховання. Радянська педагогіка тривалий час не аналізувала явище самовдосконалення. Лише в 50-х роках XX століття поступово розпочалося дослідження цього феномену, але поняття «самовиховання» і «самовдосконалення» не розрізнялися, вживалися як тотожні. Однією з перших праць, що була присвячена вивченню цього питання, стала монографія Я. Арета «Нариси з теорії самовиховання». У ній автор зазначає, що самовиховання - це освітньо-виховна робота особистості щодо себе [1, с. 2425]. Ця ідея спонукала подальше дослідження проблеми, що зумовило започаткування психолого-педагогічного підходу до іï розгляду, представниками якого стали О. Ковальов, В. Сухомлинський, С. Слканов, О. Кочетов та інші.

Значну увагу питанням самоосвіти та самовиховання приділяв В. Сухомлинський. У книзі «Сто порад учителеві» педагог наголошував на важливій ролі самовиховання для самовдосконалення особистості та закликав змалку вчити дітей оволодівати уміннями самопізнання та самовиховання. Науковець був упевнений, що за своєю суттю самовиховання передбачає віру в людину, звертання до їі честі і гідності. Його стимулом В. Сухомлинський називав почуття власної гідності, поваги до себе, прагнення стати кращим. Важливим для процесу самовдосконалення науковець також уважав формування i розвиток потреби в самоосвіті. На думку В. Сухомлинського, самоосвіта становить «єдність оволодіння знаннями на уроках і тієї самостійної інтелектуальної праці вдома, над книжкою, у якій виражається тривалий процес становлення нахилів, здібностей, покликання» [11, с. 424].

С. Слканов, досліджуючи закономірності, структуру, рушійні сили процесу самовиховання вчителя, його спрямованість на вдосконалення професійної діяльності, засоби і способи професійного самовдосконалення, використовував терміни «самовиховання» й «самовдосконалення» як синонімічні. Науковець розглядав самовиховання як діяльність, вищу форму активності особистості, у 
процесі якої саморегуляція, самоосвіта та інші дії здійснюються задля прогресивних змін тих чи тих якостей $[3$, с. 5-6]. Під професійним самовихованням учителя С. Слканов розумів «усвідомлену роботу із удосконалення своєї особистості як професіонала: адаптування своїх індивідуально-неповторних особливостей до вимог педагогічної діяльності, постійне підвищення професійної компетентності і неперервне вдосконалення ідейно-моральних та інших соціальних якостей своєї особистості» [3, с. 7]. Науковець називає основним результатом професійного самовдосконалення оптимальну відповідність між особистісними якостями та професійною діяльністю. Він також був переконаний, що джерело і рушійна сила самовиховання - це потреба в самовдосконаленні, що виникає як результат зовнішніх соціальних вимог та належного ставлення особи до них [3, с. 7].

Подібної точки зору дотримувався О. Кочетов, який також співвідносив самовдосконалення 3 самовихованням. Він уважав самовиховання найважливішим шляхом життєвого самовизначення і підготовки людини до життя в суспільстві. Педагог подавав таке трактування цього терміна: «Самовиховання - вища форма самовдосконалення духовного світу людини, при якій функції вихователя вона здійснює сама. Самовиховання можна визначити як цілеспрямований, спланований розвиток власних сил і здібностей у процесі своєї діяльності і спеціальних вправ, тренувань» $[7$, с. 58]. О. Кочетов також ототожнював самовдосконалення 3 роботою над собою, яка прискорює процес формування особистісних якостей і здібностей, збагачує життя особи, наповнює його щастям творчості. Науковець називав самовдосконалення внутрішньою організацією всього життя людини, оптимальною самореалізацією всіх їі сил і здібностей, стилем і змістом життя [7, с. 59].

У другій половині XX століття науковці досліджували лише окремі аспекти самовдосконалення: самостійне засвоєння знань (А. Громцева і В. Бондаревський), розвиток самостійності (С. Заїка), проблемне навчання (О. Матюшкін, І. Лернер), розвивальне навчання (Д. Сльконін, В. Давидов, П. Гальперін), особливості процесу становлення професіонала (Г. Балл, І. Зязюн, В. Пономаренко, С. Смирнов).

Нині терміни «самовиховання», «самоосвіта» та «самовдосконалення» розглядаються науковцями як окремі явища. Самовдосконалення досліджується у межах особистісно зорієнтованого підходу в освіті, основна мета якого полягає у сприянні особистісному розвитку студента у процесі підготовки до професійної діяльності. Особистісно зорієнтований підхід основною функцією педагога визначає створення психолого-педагогічних умов для самовдосконалення та осмисленого засвоєння студентами основ професійної діяльності. Так В. Ягупов указує, що основна закономірність педагогічного процесу полягає в єдності навчання, виховання, розвитку й самовдосконалення. На думку науковця, самовдосконалення передбачає постійну самоосвіту та самовиховання, систематичний розвиток навичок і вмінь учіння, формування мотивації навчальнопізнавальної та майбутньої професійної діяльності [15, с. 244-245].

Подібні погляди на це питання мають науковці В. Артюхова, Я. Подоляк, Я. Шведова, які трактують самовдосконалення як усвідомлену діяльність, спрямовану на найбільш повну реалізацію людиною себе як ідеальної особистості; шлях людини до досконалості моральних, розумових, фізичних та інших якостей. Вони вважають, що самовдосконалення студентів передбачає активну самостійну роботу із самовиховання, самоосвіти та самонавчання, а його мета - досконалість особистості [8, с. 7-14].

У свою чергу дослідники К. Абульханова-Славська, В. Жуков, Л. Лаптєв, А. Подольська, В. Сластьонін погоджуються в тому, що професійне 
самовдосконалення - це свідомий, цілеспрямований процес підвищення рівня своєї професійної компетенції і розвитку професійно значущих якостей відповідно до зовнішніх соціальних вимог, умов професійної діяльності й особистої програми розвитку $[10$, с. 250$]$.

На основі аналізу сучасних педагогічних досліджень, 3-поміж яких дисертаційні роботи О. Діденка, Л. Дудікової, О. Ігнатюк, М. Костенко, А. Полякова, І. Скляренко, Л. Сущенко, Т. Тихонової, А. Троца, П. Харченко, Т. Шестакової та інших, можна зробити висновок, що науковці пов'язують поняття професійного самовдосконалення 3 активною усвідомленою діяльністю, роботою особи над собою.

Вивчаючи професійне самовдосконалення майбутнього офіцера, О. Діденко визначає самовдосконалення як систематичну послідовну роботу особистості 3 удосконалення своїх позитивних й усунення негативних якостей. Під професійним самовдосконаленням майбутніх офіцерів науковець розуміє «поєднання взаємопов'язаних i взаємозалежних процесів: професійного самовиховання як цілеспрямованої активної діяльності, що має на меті формування і вдосконалення в себе позитивних й усунення негативних якостей відповідно до вимог службової діяльності офіцера, та професійної самоосвіти як цілеспрямованої роботи 3 поглиблення своїх професійних знань, удосконалення й набуття відповідних навичок i умінь під час навчання у вищому військовому навчальному закладі» [2, с. 7].

Розглядаючи підготовку майбутнього інженера до професійного самовдосконалення, О. Ігнатюк стверджує, що професійне самовдосконалення - це важливий компонент підготовки фахівців, результат свідомої взаємодії майбутнього спеціаліста 3 конкретним соціальним середовищем, під час якого він реалізує потребу розвитку професійно важливих якостей, знань і вмінь, що сприятимуть досягненню успіху у професійній діяльності [5, с. 16].

М. Костенко співвідносить професійне самовдосконалення майбутнього вчителя 3 професійно-творчим саморозвитком, який вона тлумачить як творчий саморозвиток особистості в навчально-виховному процесі, що забезпечує подальшу творчу самореалізацію у професійній діяльності і здійснюється за допомогою механізмів самопізнання, самоорганізації, самоосвіти [6, с. 5]. Із цією позицією погоджується Т. Тихонова, яка також пов'язує професійне самовдосконалення 3 професійним саморозвитком, що визначається як процес цілеспрямованого й усвідомленого самопізнання та самопроектування задля досягнення значних результатів у майбутній професії $[13$, с. 8$]$.

У своїй роботі, присвяченій вивченню педагогічних умов мотивації професійного зростання студентів педагогічних університетів, А. Поляков доходить висновку, що професійне самовдосконалення тотожне з професійним зростанням. Науковець визначає це поняття як «динамічний, неперервний процес розгортання особистісного потенціалу, потенційних можливостей, заснованих на внутрішній потребі в освіті, процес удосконалення особистості: загальнокультурних і фахових знань; системи інтелектуальних і практичних умінь і навичок; досвіду творчої діяльності; розвинених особистісних і професійно значущих якостей» [9, с. 7].

Досліджуючи проблему стимулювання професійного самовдосконалення вчителів початкових класів у системі післядипломної освіти, Л. Сущенко визначає, що професійне самовдосконалення вчителів - це внутрішній процес якісних самозмін, який відбувається за рахунок усвідомлення необхідності самовдосконалення, грамотного самоаналізу, мотивованого, цілеспрямованого й чітко організованого саморуху до ідеалу [12, с. 6]. 
Вивчаючи формування готовності майбутніх педагогів до професійного самовдосконалення, Т. Шестакова розуміє професійне самовдосконалення як процес і результат творчого, цілеспрямованого, самостійного руху особи до вершин особистісного і професійного розвитку, що здійснюється завдяки самоосвіті, самовихованню, самоактуалізації й самоменеджменту та забезпечує його творчу самореалізацію у професії [14, с. 11].

Особливо важливими для нашого дослідження є наукові праці, які розглядають професійне самовдосконалення майбутніх сімейних лікарів. Водночас у психологічній i педагогічній літературі нині майже немає праць, спеціально присвячених професійному самовдосконаленню студентів вищих медичних навчальних закладів. Чи не єдиною такою працею $є$ дисертаційне дослідження Л. Дудікової, яка вивчає формування готовності до професійного самовдосконалення у майбутніх лікарів. Науковець визначає професійне самовдосконалення майбутніх лікарів як «цілеспрямовану, систематичну й високоорганізовану діяльність, що полягає в самостійному поглибленні професійних знань, розвитку умінь, здібностей, професійно значущих якостей особистості лікаря задля підвищення кваліфікації й особистісного зростання» [3, с. 34].

Отже, аналіз педагогічних наукових праць дозволяє зробити висновок, що нині поняття професійного самовдосконалення науковці співвідносять із саморозвитком (М. Костенко, Т. Тихонова) та зростанням (А. Поляков) i трактують його як усвідомлену, високоорганізовану, систематичну діяльність (В. Артюхова, Л. Дудікова, Я. Подоляк, Я. Шведова), свідомий цілеспрямований процес (К. Абульханова-Славська, В. Жуков, Л. Лаптєв, А. Подольська, А. Поляков, В. Сластьонін, Л. Сущенко, Т. Тихонова, Т. Шестакова) та роботу над собою (О. Діденко, О. Кочетов). Науковці доходять висновку, що зміст професійного самовдосконалення полягає в підвищенні рівня своєї професійної компетентності і розвитку професійно значущих якостей, умінь та здібностей (К. АбульхановаСлавська, Л. Дудікова, В. Жуков, Л. Лаптєв, А. Подольська, В. Сластьонін). Метою професійного самовдосконалення визначається досягнення вершини особистісного і професійного розвитку (В. Артюхова, Л. Дудікова, О. Ігнатюк, М. Костенко, Я. Подоляк, Л. Сущенко, Т. Тихонова, Я. Шведова, Т. Шестакова).

Отже, враховуючи все викладене нами вище, ми визначаємо професійне самовдосконалення майбутніх сімейних лікарів як свідому, цілеспрямовану, систематичну діяльність, зміст якої полягає в самостійному поглибленні загальнокультурних і фахових знань, розвитку особистісних якостей, умінь i здібностей, необхідних для майбутньої професійної діяльності сімейного лікаря, досягнення вершини особистісного і професійного розвитку.

У педагогічній науці професійне самовдосконалення розглядається як важливий компонент підготовки фахівців. Однак подальшого дослідження потребує проблема виявлення засобів активізації професійного самовдосконалення майбутніх сімейних лікарів у процесі їхньої професійної підготовки.

\section{Література}

1. Арет А. Я. Очерки по теории самовоспитания / А. Я. Арет. - Фрунзе : Изд-во Киргиз. ун-та, 1961. - 124 с. 2. Діденко О. В. Педагогічні умови професійного самовдосконалення майбутніх офіцерів: автореф. дис. на здобуття наук. ступеня канд. пед. наук : спец. 13.00.04 «Теорія та методика професійної освіти» / О.В.Діденко. Хмельницький, 2003. - 24 с. 3. Дудікова Л. В. Формування готовності до професійного самовдосконалення у майбутніх лікарів : дис. ... канд. пед. наук: 13.00.04 / Л. В. Дудікова. - Вінниця, 2011. - 230 с. 4. Елканов С. Б. 
Профессиональное самовоспитание учителя : [книга для учителя] / С. Б. Елканов. М. : Просвещение, 1986. - 143 с. 5. Ігнатюк О. А. Теоретичні та методичні основи підготовки майбутнього інженера до професійного самовдосконалення в умовах технічного університету: автореф. дис. на здобуття наук. ступеня д-ра пед. наук : спец. 13.00.04 «Теорія та методика професійної освіти» / О. А. Ігнатюк. - Х., 2010. - 44 с. 6. Костенко М. А. Педагогічні умови професійно-творчого саморозвитку майбутнього вчителя: автореф. дис. на здобуття наук. ступеня. канд. пед. наук: спец. 13.00.04 «Теорія та методика професійної освіти» / М. А. Костенко. - Х., 2004. - 20 с. 7. Кочетов А. И. Как заниматься самовоспитанием / А. И. Кочетов. - [3-е изд., доп. и перераб.]. -Мн. : Выш. шк., 1991. - 287 с. 8. Подоляк Я. В. Самосовершенствование студента : [учеб. пособие] / Я. В. Подоляк, Я. В. Шведова, В. В. Артюхова. - Х. : ХНУ, 2011. - 171 с. 9. Поляков А. О. Педагогічні умови мотивації професійного зростання студентів педагогічних університетів у процесі неперервної освіти : автореф. дис. на здобуття наук. ступеня канд. пед. наук: спец. 13.00.04 «Теорія та методика професійної освіти» / А. О. Поляков. - Х., 2008. - 21 с. 10. Психология и педагогіка : [учеб. пособ.] / под ред. В. И. Жукова, Л. Г. Лаптева, А. И. Подольской, В. А. Сластенина. - М. : Издательство Института психотерапии, 2004. - 585 с. 11. Сухомлинський В. О. Вибрані твори: у 5 т. Т. 3. Серце віддаю дітям. Народження громадянина. Листи до сина / В. О. Сухомлинський. - К. : Рад. школа, 1977. - 670 с. 12. Сущенко Л. О. Стимулювання професійного самовдосконалення вчителів початкових класів у системі післядипломної освіти: автореф. дис. на здобуття наук. ступеня канд. пед. наук : спец. 13.00.04 «Теорія та методика професійної освіти»/ Л. О. Сущенко. - К., 2009. - 20 с. 13. Тихонова Т. В. Педагогічні умови професійного саморозвитку майбутнього вчителя інформатики: автореф. дис. на здобуття наук. ступеня канд. пед. наук : спец. 13.00 .04 «Теорія і методика професійної освіти»/ Т. В. Тихонова. - К., 2001. - 20 с. 14. Шестакова Т. В. Формування готовності майбутніх педагогів до професійного самовдосконалення: автореф. дис. на здобуття наук. ступеня канд. пед. наук : спец. 13.00.04 «Теорія та методика професійної освіти» / Т. В. Шестакова. - К., 2006.- 20 с. 15. Ягупов В. В. Педагогіка : [навч. посіб.] / В. В. Ягупов. - К. : Либідь, 2002. - 560 с.

Ольга Просіна

\section{ФАСИЛІТАЦІЯ ЯК ІННОВАЦЙНА ТЕХНОЛОГІЯ В НАВЧАЛЬНО- ВИХОВНОМУ ПРОЦЕСІ}

Просіна О. В. Фасилітація як інноваційна технологія в начально-виховному процесі.

У статті розкрито сутність поняття «фасилітація», значення фасилітованої технології у формуванні толерантного, творчого, критичного мислення. Визначені основні якості особистості вчителя-фасилітатора: атрактивність, асертивність, толерантність. Охарактеризовано необхідні навички для організації фасилітованої дискусії.

Ключові слова: фасилітація, атрактивність, асертивність, толерантність, групова динаміка.

Просина О. В. Фасилитация как инновационная технология в учебновоспитательном процессе.

В статье раскрыты сущность понятия «фасилитация», значение фасилитированной технологии в формировании толерантного, творческого, 